Luka Repanšek

University of Ljubljana*
UDK 811.163.6'373.21(497.473)

DOI: 10.4312/linguistica.55.1.59-72

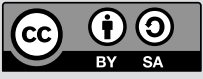

\title{
TOWARDS A CLARIFICATION OF THE HISTORY OF THE SLOVENE RIVER NAME SOC̆A
}

\section{COMMON SLOVENE *SÓČA}

The immediate source of the Common Slovene river name *Sóća (= dial. (Natisone) Só:ča, Resian (Bila) Sóča) ${ }^{1}$ may be unproblematically reconstructed as Slavic *Soća, regularly continuing an older *Sunča $\bar{c}$. The original accentual pattern of this feminine noun cannot be recovered but such ambiguity is typical of the western and southern Slovene feminine $a$-stems with a long root vowel. It is likely that the name originally

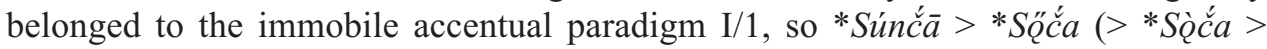
*Sóća), as is the case with, e.g., *Sọtrb/bla (Sotla) <*Súntu/ila and in clear opposition to the coherent group of river names with simple disyllabic structure $*(C) C_{1} V C_{2} \bar{a}$, which feature regular circumflexion and accompanying (in my view undoubtedly internally Slavic) lengthening of the originally accented vowel, e.g. *Zilía $<* 3 \tilde{i} \bar{l} \bar{a},{ }^{2}$

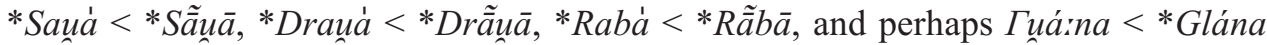
$(<*$ Glaná $)<*$ Glāna $(=*$ Glänāa $) .{ }^{3}$ The substitution of Slavic short *u for Romance

* Oddelek za primerjalno in splošno jezikoslovje/Department of Comparative and General Linguistics, Filozofska fakulteta, Aškerčeva 2, 1000 Ljubljana, Slovenia; luka.repansek@ff.uni-lj.si

1 See Šekli (2008: 166), Steenwijk (1992: 310).

2 The reconstruction is based on the recently acquired dial. attestation Zlíca (Žabnice/Camporosso) - cf. the Italianised form Slizza - with regular vowel reduction in the paroxytonon, which clearly points to the diminutive *Zilíca (AP $\left.F_{1}\right) \leftarrow *$ Zilía (AP $b$ ).

3 Note here that the specifically Slavic accent shift known as the Dybo's Law must be chronologically posterior to the integration of the oldest core of pre-Slavic toponymic material. Consider in this respect a few truly unambiguous cases which show accent progression but were for one reason or another regularly exempt from the subsequent rule of accent retraction by Ivšić-Stang's Law, so that subsequent integration into the productive patterns as they existed after the operation of both uniquely Slavic accent shifts is unthinkable. Such are Sln. Cèlje $<*$ Celié $<*$ Celbiè $<*$ Celiiè $<$ *Kelêia $\leftarrow$ Rom. *Keléia with contraction-induced inhibition of subsequent accent retraction, and the category of AP E accentual units such as Čak. Osör (Rom. *Ápsaru $\rightarrow$ Slav. * Ásaru $>*$ Osórb), Štok. Mòsor (Rom. *Más(s)aru $\rightarrow$ Slav. *Mãsaru $>*$ Mosórz), Sln. Celôvec $(<*$ Cub/ilónucb $<$

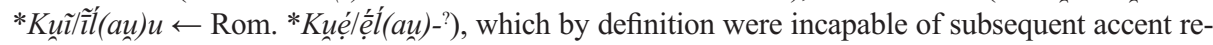
traction. I would also include here *Uýdbnb, *Uýdbna > Common Slovene *Vidən, *Vidna with preserved quantity of the accented /í:/ throughout the paradigm. Note that Ter (Subid) Vid'an, Gsg Vid'na (quoted by Šekli 2009: 153) <*Vidon/*Vidna $<*$ Uydínъ $/ * U y ́ d b n a$ does not in fact point

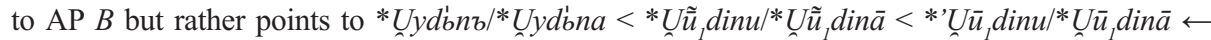
Rom. *'Ut/dinu. Note that the latter (mis)interpretation is in fact impossible even under an assumed generalisation of the $/ i \dot{i}: /<$ neo-acute $* y /$ recent Slovene acute $* i$ from the nominative singular. 
open $*_{o}(=/ \mathrm{J} / ?)<$ VLat. $* \breve{o}$ (and subsequent development of the back nasal vowel $* Q$ for the accented tautosyllabic sequence *un) is the theoretically expected outcome of phonetic adaptation before the rise of the new Slavic $* o$ from Proto-Slavic $* a$. The regular substitution of the Romance affricate $*_{c} \sim *^{*} \dot{c}(<* \dot{t}<* t i, * k i)$ in the earliest layer of Romance loans into Slavic, which predate the rise of the genuinely Slavic ${ }^{*} c$ by second and third palatalisation processes, is the corresponding Slavic affricate $*^{*} \dot{c}\left(<* k^{E}\right) .{ }^{4}$ Note that this is the only theoretically expected outcome, neatly corroborated by a set of early loans into the type of Slavic idioms that do not coalesce the older

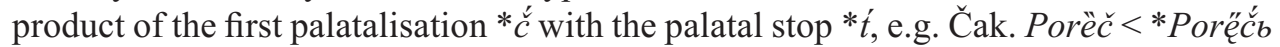

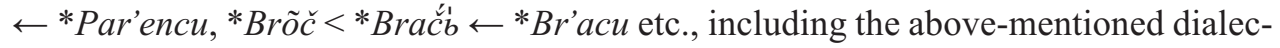
tal Slovene forms.

The Slavic adaptation of the Romance prototype points to something like *'Sonco or rather and given the likely point of contact, *'Sonč $o$. The morphological adaptation of the originally masculine name (as undeniably proved by the older sources) and its integration into the class of Slavic feminine $a$-stems is a fully systematised process, based on gender attraction of the premodifier to a feminine head-word in the underlying noun phrase (i.e. the onomastic model, for which see Šivic Dular 1998). A more serious point of disagreement between the Slavic adoption and the organic reflex of the hydronym as inferable from the contemporary Friulan outcomes Lusinç (standard form), dial. L'Isùns (Aquileia), il Lusins (Flumisel/Fiumicello), ${ }^{5}$ however, lies in the fact that the Slavic form presupposes a source with early aphaeresis of the initial vowel. But Friulan - the contemporary form of the donor language - seems to have preserved no trace of such a variant. It is possible that the internal Friulan otucomes such as Lusinç \& c. may go back to a later non re-analysable conglomeration of the Old Friulan masculine definite article $l u(<*$ illum $)$ and a form such as *Sončz $<*$ Sontio, but it is equally likely that they simply reflect a sporadic case of vowel metathesis (in the case of standard Friulan variant in a form theoretically borrowed from the sonziaco Friulan with $u<*^{*}$ ), or

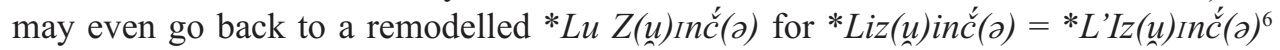
$<* I z$ 'ontón. Note that il Lusins attested in Flumisel/Fiumicello may speak in favour of the possibility that at least some of these forms may have undergone metathesis, granting that the expected outcome *L'Isùns (with expected $u<*^{*}$ /_ NT) would have undergone subsequent agglutination. Be that as it may, a pre-form with an anlauting (unaccented!) vowel, which seems to underlie the Friulan reflexes of the river name, cannot have been the source of the integration into Slavic as one would then expect Slavic **Zoća - the process of sonorisation of intervocalic consonants in the precursor of Friulan, as is inferable from a number of transparent cases, predates the contact between the Romance and the Slavic idiom. It goes without saying that the attested forms

4 Pace Ramovš HG II §152, id. (1936: 27, 51), who proposes to start from **Sot́a (similarly Šturm 1927: 59-60, repeated in Furlan 2002: 33 and ESSZI s.v. Soča; sceptically Šekli 2008: 166).

5 For older attestations see Di Prampero (1882 s.v.) and Pirona, Vocabulario friulano (1871), who records Lusìnz and (L)isùnz.

6 The bilabial element of the original diphthong is only preserved after labials, cf. puint $<*$ pənto vs. frint $<*$ frondo etc. 
also exclude the possibility of a specifically Slavic case of aphaeresis (cf. *Nynz for Aenona, on which see Schramm 1981: 58, 262,307).

If the manuscript tradition is to be trusted, the first Latinised attestations of the trisyllabic variant are Cassiodorus' Sonti fluenta (Var. epist. I,18,10) and the famous prepositional phrase super Sontium (ib. I,29), reported in the early $6^{\text {th }}$ century. All other attestations of Sontius which directly refer to the river, including the $8^{\text {th }}$-century account of Paulus Diaconus (Hist. rom. XV, 20, p. 214: iuxta Sontium flumen, qui non longe ab Aquileia labitur $),{ }^{7}$ may simply be reproductions of an established manuscript variant. Note that the entire corpus of the earliest literary attestations of the hydronym refers to or briefly recounts one and the same historical event with AD 489 as its indubitable terminus post quem. The question of the source of the variant Sontius thus cannot receive an easy answer, especially in the light of the fact that Cassiodorus, who presumably would have been aware of the organic, autochthonous name of the river, seems inclined to indiscriminative use of the original, four-syllabic Isontius beside the truncated variant (see Cass., Chron. p. 159, 1319-1321: ad Isontium, and cf. gurgites Isontii in Paul. Aquilei. ( ${ }^{\text {th }}$ c.), carm. II,1,v.5). Since aphaeresis is not strictly speaking a sound change, it most often goes back to deglutination, normally resulting from the reinterpretation of morpheme boundaries. A putative Sontius could easily have been produced by deglutination in cases such as *de Esontio $>*$ de Sontio or through phonetic hyperinterpretation of Isontio as $i(n)$ Sontio with VLat. is- $<*$ ins etc. None of this can be verified, however. Another, rather obvious and hence already proposed $^{8}$ possible source of the alternative form Sontius is the contracted and presumably reinterpreted form of the place name Ponte (= Lat. abl.-loc. sg.) Sonti(i) (= Lat. gen. sg.), first attested in Tabula Peutingeriana at segm. III,5 as the designation of a Roman mansio (see Vedaldi Iasbez 1994: s.v. Ponte Sonti). From an underlying *Ponte Esonti $(i)>*$ Pontesonti the way to Ponte Sonti and subsequent extrapolation of Sontius, corresponding to the new genitival form of the river name, is easily envisaged. This scenario may be oversimplistic, however, since there can be no knowing whether the reported form of the place name is in fact organic or perhaps artificially (re)produced in transmission. It is noteworthy that the compiler of the Tabula seems to have had no notion of the actual river name, simplistically superimposing the $f$. Frigido (III,5) on the lower course of the actual Isontius and ending it in a rather large lake (no designation) near Aquileia. This means that in the case of Sonti reported on the Tabula there would have been no source of possible (hyper?)correction. Note that Yordanes is the only author who treats the two components of the place name as independent units (Getica 57,292-293, p. 133: ad pontem Sontii), but this must surely be secondary. Both genitives pontis Sontis (Fasti vindob. prior. II.50, p. 317, 1. 490) and ponte Sontis (Auct. hauniense II.50, p. 317, 1. 490) ${ }^{9}$ clearly point to Pons Sonti-/

7 For the attestations see Vedaldi Iasbez (1994: 109-110).

8 See Brusin (1924: 225-226), Niedermann (1931: 3ff.).

9 For the sources see Vedaldi Iasbez (1994, s.v. (Ae)sontius/Isontius). 
Ponte $=$ Sonti-,${ }^{10}$ which was by that time quite evidently acquiring the status (limited to manuscript tradition!) of a dithematic toponymical unit.

It is perhaps worthwhile to stress the fact that every single testimony of the river's name, including the autochthonous Friulan outcomes, refers to the lower course of the Soča between Goriza and the Gulf of Trieste. The distorted image of the river system in this part of the Friulan plain typical of all classical geographers goes hand in hand with the fact that the upper course of the river was simply too insufficiently known to afford the right connection. While the Frigidus river must have been familiar even to an outsider due to its strategic position, the complicated net of tributaries dominating the (south-)eastern Friulan plain, starting at Sovodnje (Savogne dal Lusinç/Savogna d'Isonzo) will have remained rather perplexing. There is all the reason to believe, however, that locally the correspondence between the river's name as handed down from prehistory and the entire stretch of its course was unquestioned. Since the contact of the incoming Slavs with the Roman-speaking population was not in fact limited to the south-western perimeters of the penetration wave (the contact area stretches from south to north in a more or less compact belt), the geographical parameters of this particular case of name-integration are nevertheless not determinable. ${ }^{11}$

\section{ROMANCE *VE'ontó}

The Friulan continuations of the pre-Romance source, viz. Lusìnç/Lisùns, are silent as to their ultimate origin. Due to vowel harmony ${ }^{12}$ of unaccented $e \sim i$ they are both

10 Pace Vedaldi Iasbez (1994: 113) there is no need to assume a syncopated Venetic Sontis. Rather the genitive singular Sonti (for Sontii) was interpreted as an $i$-stem in the process of disintegration of the original syntactic relationship between both members, complete in ponte Sontis = virtually gen. sg. to *Ponte-sonti-.

11 The case of Sotla $<{ }^{*}$ Sọtz/bla (a tributary of the Sava in Eastern Slovenia) is most likely irrelevant for the question of the date and the source of the aphaeresis (similarly sceptical SVI II: 210-211 and ESSZI: 390 but cf. Furlan 2002: 33). Nothing is known of the history of this particular river name and the existing attestations are much too late to provide a better starting point than what can be inferred from the historical phonology of the contemporary forms. Slavic *Sálúntu/ila points to *S'al'ol'untVlV - a form that is not immediately transparent. If the vowel in the second syllable is the result of later (but pre-Slavic!) anaptyxis (cf. in this respect the likely

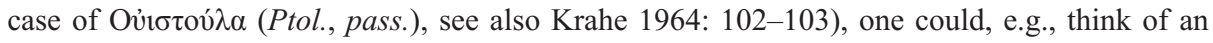
agent noun *snt-ló- to PIE *sent- 'move, go'. On the other hand, the * $t$ could also be an integral part of the suffix such as $*_{-}$tlo- $\sim *_{-}-t_{l} H_{2}$ (note that $* t$ as the result of consonantal epenthesis in a ${ }^{*}-n-l$ - cluster is not at all likely in a voiced environment). Alternatively, we could be deal-

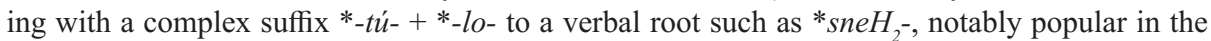
derivation of river names, but there is no knowing whether a putative tautosyllabic $*_{n} H$ would result in something like *an $/ *^{*} o n / *$ un in the particular linguistic system that generated our source. Note that both *Sau- $a^{?} s^{?}$ and ${ }^{*} D r a u-a ?{ }^{?}$ are likely to be more specifically Pannonian rather than just broadly Old European and that it may be important in this respect to note that the Pannonian reflex of (at least) the plain syllabic nasal is in fact *uN.

12 I am grateful to Prof. Dr. Franco Finco for reminding me of this important fact of Friulan historical phonology. 
derivable either from $* I z^{\prime}$ onto $<* \bar{I}^{\prime}$ 'ontio- or ${ }^{*} E z^{\prime}$ onto ${ }^{\prime}$, the latter from *Ais'ontio-, *Ois'ontio- or * Is'ontio- (assuming * $i[-$ accented $]>(* e \sim) * e$ rather than ${ }^{*} I z$ 'onto $<$ * Is ${ }^{\prime}$ ontio-, but neither of these developments is in fact demonstrable solely on the basis of Friulan historical phonology). The remaining alternative *Eis'ontio- is problematic because the reflex of *ei in a name integrated into Latin after the monophthongisation of the inherited $* e i$ is simply irrecoverable. If such a sequence were borrowed before the $2^{\text {nd }}$ half of the second century BC, which in the case of Soča is in fact not impossible, and if it was identified with the long mid-high monophthongisation product of Old Latin $* e i$, then it would merge with the latter and eventually be raised to ${ }^{*} \bar{i}$. In unaccented position $* \bar{l}$ would retain its quality throughout the development towards Vulgar Latin. If, however, the integration post-dated the final raising, a non-autochthonous unaccented * $e i$ would probably either be preserved or join the VLat. unaccented *e, depending on how late the borrowing was made. Due to the lack of instructive examples, these developments ultimately have to remain speculative. Note that if the $5^{\text {th }}$-century attestation Isontius (Cass., Chron., v.s.) can be taken at face value, however, this would provide a more solid argument for a direct development of unaccented *e $(\sim * e)(<* a i$, $* o i$ and possibly $* i$ ) to $* i$ (which in turn would then be lowered to $*_{e}$ if /_ $\$ \mathrm{~V}[+$ low]).

The aphaeresis signalled by the resegmented Ponte Sonti in Tabula Peutingeriana may in fact point to a stage with a low front vowel in the anlaut. Such a putative Esontius $=*$ Es'ontio vel sim. (the exact developmental stage of the auslaut is irrelevant here), which is more than likely to represent a stage older than the one reported by Cassiodorus, may also be reflected in the oldest attestations of the hydronym in the two epigrapical sources Inscr. Aqu. 1.96 = AE 1926, 108 and Aquileia nostra 1996, 109 $=A E 1996,695$. As is known, both these sources refer to the originally indisputably dehydronymic river deity Aesontius. ${ }^{13}$ At least one of the inscriptions dates back to the end of the first century $\mathrm{AD}$. If the sequence $<\mathrm{AE}>$ is the archaising graphic representation of the unaccented VLat. *e (perhaps still an open front vowel at this stage), it would easily point to a source with an anlauting * $a i,{ }^{*} o i$ and possibly unaccented short $*_{i}$ (if subsequent lowering to $*_{e}$ is assumed). If, on the other hand, the attested spelling reflects the only other possible phonetic reality, the source will have had an analuting $* a i$, with subsequent development towards $* i$ through $* e$, possibly implicitly preserved in *Ponte Esonti $(i)$. As the only truly unlikely source one should mention the long unaccented $*_{i}$ as this would have been reflected as $*_{i}$ throughout. ${ }^{14}$

13 The masculine gender of the deity itself is of course dependent on the grammatical gender of the Latinised river name, which is the direct source of the transonymisation.

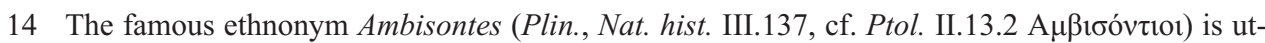
terly ambiguous since the exact location of this Alpine tribe is still very much disputed (see Šašel 1972: 140-144, Šašel Kos 1997: 23-24 and pass., contra, e.g., Alföldy 1974: 68, Scherrer 2002: 32). Given the evidence of, e.g., Ambarri $<*$ Amb-arar-o- $\leftarrow$ dehydronymic to *Arar- (on the latter see K. Ihm, RE I,2 = 1894, pp. 1795-1796), it is clear that the $i$ reported in the second syllable, should the name reflect a compound of *ambi- and *Isont- rather than *Sont-, reflects the vocalic anlaut of the governed member, the auslaut of the preposition being regularly elided in such cases. However, it should be remembered that the name reflects a Latinate form of the ethnonym (not at all necessarily Gaulish since *ambi- 'around' could just as easily have been produced in 


\section{PRE-ROMANCE *(a/o/e)is-o/a(-)nt-i $\dot{\bar{a}}$}

The correct etymological connection of the underlying hydronym with the PIE root (in modernised notation) ${ }^{*} H_{1}$ e is $H_{2^{-}}$'kräftigen; antreiben' (LIV²: 234) has already been proposed by Krahe (see Krahe 1953 s.v. and cf. Krahe 1964: 56, IEW: 299-301, Bezlaj SVI II: 204, ESSZI: 386-387 etc.). Both the name's phonetic and morphological structure are transparently Indo-European and unspecifically so, meaning that neither of its outward features are diagnostic in terms of a specific linguistic affiliation. ${ }^{15}$ If one also accepts the likely connection of the morphological structure of the suffix with the (nearly suffixal) element -antia attested in numerous European river names, simple forward reconstruction would demand a straightforward feminine present participle formation * $\mathrm{H}_{1} i \mathrm{SH}_{2}$-ñt-i $\mathrm{H}_{2}$ - (corresponding to the masculine * $\mathrm{H}_{1}$ éis $\mathrm{H}_{2}-$ ont- $/{ }^{*} \mathrm{H}_{1} i s \mathrm{H}_{2}$-ngt-'

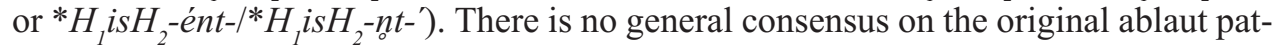
tern of the present active participle (amphikinetic?/hysterokinetic?), but it seems safe to assume, at least on grounds of the external comparative evidence, a zero grade stem for the feminine counterpart, although the generalisation of the full-grade root cannot be

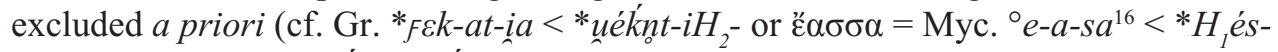

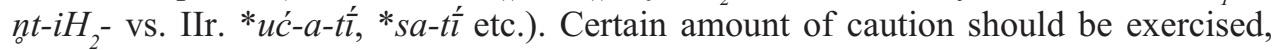
however. The clearly transitive meaning of the root ${ }^{*} H_{l}$ eis $H_{2}$ - as set up on the basis of the attested members of the averbo is as a present participle in its agentive meaning 'the impelling, stimulating, invigorating one' (the latter not in the sense of the otherwise acceptable and attested semantic motivation 'nourishing'!) rather unsuitable for a rive name. The usually assumed motivation such as 'the quickly moving one' et sim. is of course completely ad hoc and seems to be based more on our own projection of the naturally assumed possible qualities of a river than on any positive evidence.

Sifting through the available comparative data, however, it immediately becomes apparent that the underlying transitive semantics of the root may be misleading, since they seem

any Venetoid linguistic system and nothing really tangible is known of the productive patterns in the formation of ethnic names in these languages), which is apparent at least from the fact that it has been integrated into the third declension. If the ethnic name reflects *Amb-isont- and if it should turn out that the underlying hydronym indeed refers to the Soča river, the implicit underlying form *Isont- is in fact the oldest available testimony of the pre-Romance pronunciation of the indigenous name. Most interestingly it would in fact point to an original $* i$.

15 Contrary to some recent attempts to offer a dissenting view (see, e.g., J. B. Trumper, Ce fastu 82/2 (2006), pp. 151-169, id. in F. Finco (ed.), Atti del secondo convegno di toponomastica Friulana, Udine, 2007, pp. 279-326), there will of course be no need to invoke a specifically Celtic etymology. Not least for the reason that there can be no talk of a Celtic toponymical layer in this part of the Southeastern Alps and that the assumption of the process theonym $\rightarrow$ hydronym (even if external derivation is assumed after all) does not in fact represent the typologically unmarked pattern. Note that the putative pre-Romance etymon *ais- (sometimes quoted as zero-grade *is-) with the underspecified and rather random meaning 'water' or similar (cf. Frau 1978: 71 and repeated as a possibility in ESSZI: 387, see also DTFT: 438), proposed by a number of older authors (see SVI II: 203-204 for a useful overview) is of course nothing else but the inadequately interpreted * $H_{1}$ éis $H_{2}$ - appearing across a wide range of European river names.

16 See Morpurgo Davies (1978) with bibliography. 
to have been (rather inevitably) based on the conspicuously causative/factitive meaning of the attested formations. As nasal-infix presents Ved. iș-nắ-ti 'bring sb. in quick movement, spur' (co-occuring with the rare active *'-ielo-present $i s-y a$ - 'send' $=$ Av. iš-iia- 'spur, set going') and Gr. ivóo 'expulse, empty out' (both regularly $<* H_{l} i s-n e ́-H_{2}-{ }^{*} H_{l} i s-n-H_{2}-$ ), together with the old extended forms in *-ie/o- $\left({ }^{*} H_{l} i s-n-H_{2}-i e ́ l o ́->i s-a n-y a ́\right.$ - 'stimulate,

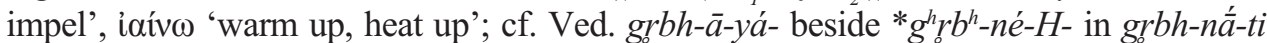
etc.), carry a clearly derivationally motivated causative meaning (cf. in this respect the clearly causative Ved. $p r-n \underline{a}-t i$ 'fills (up)' as opposed to the originally fientive Aktionsart of the verbal root ${ }^{*} \mathrm{pleH}_{l}$ - etc.). The same secondary causative function may also be unproblematically assumed for the reduplicated present ${ }^{*} H_{l} i-H_{l} e_{l} i s H_{2}-{ }^{*} H_{l} i-H_{l} i s H_{2}^{\prime}-$ in Gr. *īha- $\rightarrow$ ióoual 'heal' < *'vivify, envigorate' (on the latter see García Ramón 1986), and of course the formal causative attested in Indo-Iranian. ${ }^{17}$ Quite expectedly, the only noncausative formations are the internally IIr. intransitive zero-grade present in *-éie/o- (Ved.

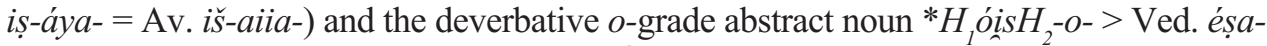
'running (after)' (cf. RVS V.66.3: éșe rathănām as clearly opposed to other instances of ésa- 'searching (for)' to iș- 'seek'). Ved. eșá-, however, which is multiple times attested as the epithet of Vișnu, meaning 'swift, quick' (cf. RVS II.34.11, VII.40.5, VIII.20.3), may represent the participial agent noun ${ }^{*} \mathrm{H}_{1} \mathrm{ois}_{2} \mathrm{H}_{2}-\mathrm{o}^{-}$, but it may just as well belong with Avestan aēsa- 'strong, potent', which continues a possessive $\mathrm{o}$-grade ${ }^{*} \mathrm{H}_{1} \mathrm{oisH}_{2}$-ó- (in all probability a Gmc. * $\chi$ raua-type adjective), completely parallel to the equally possessive derivative in -ró- as continued by Ved. iși-rá- 'lively, active, strong' $=$ Gr. iєpó $\varsigma^{18}$ 'holy ...' <* $\mathrm{H}_{i} i \mathrm{SH}_{2}-$ ró- and neatly preserved in a number of European hydronyms such as 'Iøápas (Strab. IV,6,9), 'I $\sigma \alpha \rho($ os) (Ptol. II,10,6), Isara (Liv. 21,31,4), Germ. Isar, Thrac.

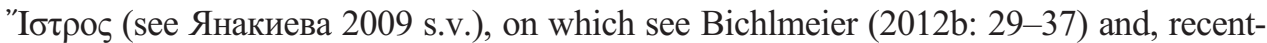
ly, Repanšek (2015: 786). Lastly, the primitive feminine root-noun * ${ }^{*}{ }_{1}{ }_{\text {ó }} i \mathrm{H}_{2}-{ }^{*}{ }^{*} \mathrm{H}_{1} i \mathrm{SH}_{2}{ }^{\prime}$ continued by IIr. *iš- *'strength, vigour, invigoration, stimulation' (cf. the abstract feminine noun * $\mathrm{H}_{\mathrm{H}} \mathrm{ois} \mathrm{H}_{2}-\dot{e} \mathrm{H}_{2}$, , probably preserved in the $\mathrm{ON}$ denominative eisa 'to rush' < ${ }^{*} \mathrm{H}_{1} \mathrm{ois} \mathrm{H}_{2}=e \mathrm{H}_{2}$-ié/ó-) $)$ and the $\mathrm{o}$-grade abstract in -mo- ( ${ }^{*} \mathrm{H}_{1}$ óis $\mathrm{H}_{2}-m o->\mathrm{Av}$. aēšma- 'anger, rage', Gr. oĩ $\mu \alpha$ 'rush, raging attack') are silent as to the verb's original voice, as are the possessive Caland adjectives. However, at least on the strength of the deverbative abstract ésa- (and perhaps eșá- if it represents its corresponding derivational pair) it is possible to suspect that the original meaning of ${ }^{*} H_{1}$ eis $H_{2}$ - was indeed 'to be/become (?) set in motion' vel sim. and thus essentially intransitive. This would successfully account for the derived semantics (secondary semantic shifts included) and, most importantly, provide a suitable base for the active present participle ${ }^{*} \mathrm{H}_{1} i \mathrm{SH}_{2}-n t-i \mathrm{H}_{2}$, which very much parallel to the possessive feminine adjective ${ }^{*} \mathrm{H}_{1} i \mathrm{H}_{2}-\mathrm{ré}_{2} \mathrm{H}_{2}$ - could theoretically be pressed into service of an

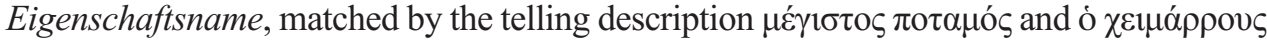
by Herodianus (Hist. rom. VIII.4.1/2). ${ }^{19}$

17 For the attestations see EWAia I: 271-272, García Ramón (1986), Gotō (1993: 128-133), Kellens (1995: 13), Werba (1997: 450-451).

18 On the internal history of iєpó $\varsigma<*$-ero- see Peters (1980: 325).

19 For the identification see Vedaldi Iasbez (1994: 112). 
As anticipated above, the alternative starting point *Aisontio- $/ *$ Oisontio- is only explicable, however, if one starts from a possessive denominal derivative $* \mathrm{H}_{1} \mathrm{OisH}_{2}-\dot{e} \mathrm{H}_{2}$ (i.e. the Greek type * $\varphi$ ov ' 'manslaughter'). As already correctly interpreted by Krahe (1953: 119; cf. Greule 2007: 117 et passim), the North-Germanic parallel *Eisandi is only indirectly comparable, seeing that the latter is in fact a deverbative participial formation to ON eisa < PGmc. *aisonnan 'rush forward' (in turn built to the exact same deverbal abstract * $\mathrm{H}_{1} \mathrm{oisH}_{2} \mathrm{e}^{\mathrm{H}} \mathrm{H}_{2}-$ ). There is no positive proof, however, that a hy-

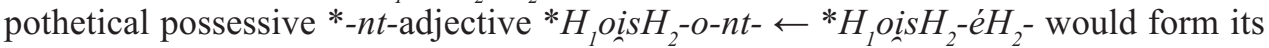
feminine in ${ }^{*}-\mathrm{iH}_{2}$ ( (or, for that matter, ${ }^{*}-(\mathrm{i}) \mathrm{eH}_{2}-$ ). The case of clearly denominal river names such as Albantia, Aquantia etc. is ultimately indecisive in this respect: either the ubiquitous sequence-antia is interpreted as the reflex of the feminine form of the *-nt-possessive, or - in avoidance of circularity - as a ready-made toponymical suffix, mirroring a virtual ${ }^{*}$-ntiH ${ }_{2}$ ( cf. Repanšek 2015: 787). ${ }^{20}$

The question is of course inextricably bound with the controversial problem of Old European hydronymy. It was silently assumed above that the $a$-vocalism of the theoretical starting point ${ }^{*} \mathrm{H}_{1} \mathrm{O}_{\Omega} \mathrm{SH}_{2} e \mathrm{H}_{2}$ - necessitates the same vowel quality in the suffix and that this somehow dictates the realisation of the suffix $-i H_{2}-$ as $*_{-}-i \bar{a}<\mathrm{i}>>$, so that one would be inclined to start from *Aisanti $\breve{a}$. The regular change of the short PIE *o to short * $a^{21}$ and the realisation of the syllabic nasal $*_{n}$ as $*$ an (if $* H_{l}$ ois $H_{2}-o-n t$ - is assumed as the strating point, the change of *-o-nt- to *-a-nt-would of course be equally regular), paired with the likely (morphological) substitution of the biphonemic sequence ${ }^{*}-i \bar{a}$ (or less

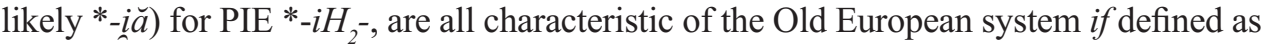
an actual linguistic stratum with the pertaining set of system-specific phonological and morphological transformations. ${ }^{22}$ Note that we are only forced to presuppose an underlying *Aisantiă $\breve{a}$ in case the epigraphic attestation of river name, viz. Aesontius*, is taken at face value. The same goes for ${ }^{*} H_{I}(e) i s H_{2}-n t-i H_{2}->*(E) i s-a n t-i \bar{a}$, but only if one does not want to assume the tenuous possibility of the generalisation of the $o$-grade suffix $\left({ }^{*} H_{1}(e) i s H_{2}-o n t-i H_{2}-\right)$. Any reconstruction that would start from an $*$-ant-i $-\bar{a}$, however, must assume that the name must rather early on have passed through the phonetic filter of an idiom that typically preserved the PIE *o intact. Given the areal distribution of the autochthonous linguistic systems in the wider region of South-Eastern Alps prior to the arrival of Gaulish, the only serious candidate is the Venetic complex. The integrated unit *Aisantia $\breve{a}$ or *(E)isanti $\breve{a}$ would potentially be liable to renovation to *Ais/(E)is-ont-i $\ddot{\bar{a}}$, but only under the assumption of possible interference from the autochthonous Venetic

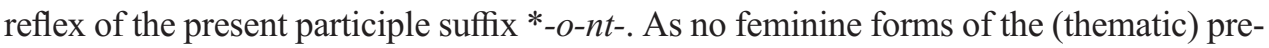
sent active participle are attested in Venetic, however, the possibility of an assumed correspondence between *-ant-ina $\breve{a}$ and ${ }^{*}$-ont-i $i \bar{a}$ is impractical to test in any more or less direct

20 As is the case, for example, in North Germanic (see Greule 2007: 118, 121).

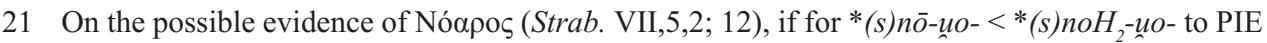
*(s)neH $2_{2}^{-}$'baden, schwimmen' (LIV': 572-573), I would restrict this sound change to the system of short vowels (see Repanšek 2015: 785, ft. 22).

22 Such an approach is now tentatively advocated by Bichlmeier (e.g. 2012a, 2012b et pass.). 
way. Feminine personal names such as vho.u.go.n.ta (LVen., Es 85) are uneluciadating. Although diachronically such names are based on a true deverbal active participle, they in fact represent a productive pattern of feminine motion and function synchronically solely as feminine versions of masculine names. ${ }^{23}$ The form Voltaronti, attested at Ig (CIL III.3877), on the other hand, indirectly probably points to the preservation of the old shape of the feminine participial suffix *-ont- $\bar{l}$ at least for this peripheral dialect (see Stifter 2012: 258 and Repanšek forth.). Since the Venetoid linguistic system attested in the ager is in many respects more archaic than the more central Venetic, however, the latter might have innovated in the direction of *-ontia . Be that as it may, an equatable sequence *-onti $\bar{a}$ - would certainly have been provided by the system through the oblique cases of the feminine paradigm.

It must in any case be assumed, however, that should the hydronym belong to a layer of toponymy older than the one generated by Venetic, the auslauting sequence *-ant-i $-\bar{a}$ will eventually have been remade into a masculine *-ont-io- - a form that is indeed reflected by all the historical attestations of the river name, including its modern Friulan reflexes. Whether this process is intrinsically bound with the ultimate Latinisation of the name (*-ont-i $\breve{\bar{a}}>$-ontia $\rightarrow$-ont-ius) or should be recognised as the result of Venetic recharacterisation of *-anti $\bar{a}$ is not unambiguously determinable either. It is true that a Venetic *-ont-ios would result in the syncopated *-ont-is $>*_{\text {-ont-s, }}$, but any Venetic stem in -(i)s would still be interpretable as corresponding to the Latin -ius, not least for the fact that the oblique cases still regularly preserved the unsyncopated shape of the sequence *-io-. At least systematic masculinisation of feminine river names is well attested for Latin, while the possibility that the same could be claimed for Venetic is of course completely open to conjecture.

If contrary to the above the Old European stratum is rather perceived as a static network of the oldest, undifferentiated Indo-European toponymical heritage, Venetic historical phonology (and morphology, for that matter, but here the involved morphological patterns may have already become unproductive by the time of the first attestations, so that any potentially archaic trait is self-explanatory and useless for our purposes) should account for the pre-literary form of the name. In this respect only ${ }^{*} \mathrm{H}_{1} \mathrm{oisH}_{2}-\mathrm{o}-\mathrm{nt}^{-}{ }^{-}$is the possible starting point, while the participial ${ }^{*} \mathrm{H}_{I}(\mathrm{e}) \mathrm{is}_{\mathrm{S}}-\mathrm{nt}_{\mathrm{o}}-\mathrm{i} \mathrm{H}_{2}-$ is only conceivable as an alternative under the assumption of the generalisation of an $o$-grade suffix based on the masculine/thematic stems, for which no supporting evidence can be adduced, however. Note that a putative Venetic reflex *(E)is-ant-? $<* H_{l}(e) i s H_{2}-n t-i H_{2}-24$ is far less likely as a starting point, as one would then have to assume some secondary process through which the resulting vocalism in the suffix would have been analogically adapted to the shape of the masculine participial stem. Although, admittedly, this possibility is not at all unimaginable, it must remain for the time being impossible to prove. Needless to add, both in terms of the shape of the

23 Contrary to Lejeune (1974: 83), the possibility of a shared form of the present active participle for the masculine and the feminine in Venetic (as is the case in Latin) is virtually nil.

For Venetic $* a N<\mathrm{PIE} * N_{0}$ cf. iiuva.n.t.s. (Es 25$)<* H_{22} i u-H_{30} n-t-$. 
final morpheme as well as the distribution of the inherited $*_{-}$ont-vs. $*_{-}$nt-i $H_{2}$ - nothing decisive can be inferred from the available linguistic material. ${ }^{25}$

\begin{abstract}
Abbreviations
$\mathrm{AP}=$ accentual paradigm; Av. = Avestan; Čak. = Čakavian; Gr. = Ancient Greek; Lat. = Latin; Myc. $=$ Mycenian; ON = Old Norse; PGmc. $=$ Proto-Germanic; PIE = Proto-IndoEuropean; Rom. = Romance; RVS = Rgvedasam̆́hitā; Slav. = Slavic; Sln. = Slovene; Štok. $=$ Štokavian; Thrac. $=$ Thracian; Ved. = Vedic; Ven. = Venetic; VLat. = Vulgar Latin
\end{abstract}

\title{
Bibliography
}

AE = L'Année épigraphique. Paris, 1888-

ALFÖLDY, Geza (1974) Noricum. London/Boston: Routledge and Kegan Paul.

BICHLMEIER, Harald (2012a) ,Anmerkungen zum terminologische Problem der alteuropäischen Hydronymie samt indogermanistischen Ergänzungen zum Namen der Elbe. " Beiträge zur Namenforschung 47/4, 365-395.

BICHLMEIER, Harald (2012b) „Einige ausgewählte Probleme der alteuropäischen Hydronymie aus Sicht der modernen Indogermanistik - Ein Plädoyer für eine neue Sicht auf die Dinge." Acta linguistica Lithuanica 66, 11-47.

BRUSIN, Giovanni Battista (1924) „Il nome dell'Isonzo." Rivista della Società Filologica Friulana 5/3, 223-226.

CAMPANILE, Enrico (ed.) (1990) Rapporti linguistici e culturali tra i popoli dell'Italia antica, Pisa, 6-7 ottobre 1989. Pisa: Giardini editori e stampatori in Pisa.

$\mathrm{CIL}=$ Corpus inscriptionum Latinarum.

DI PRAMPERO, Antonio (1882), ,Saggio di un glossario geografico friulano dal VI al XIII secolo." Atti del Regio Istituto Veneto di Scienze Lettere e Arti 5/7-8, 1-236.

DTFT $=$ CINAUSERO HOFER, Barbara/Ermano DENTESANO con la collaborazione di Enos CONSTANTINI e Maurizio PUNTIN (2011) Dizionario toponomastico. Etimologia, corografia, citazioni storiche, bibliografia dei nomi di luogo Friuli storico e della Provincia di Trieste. Udine: Edizioni Ribis.

25 An original *-ont-(i)io-, i.e. a deadjectival *io-derivative (?) based on a *-nt-participle, however, does not seem to be a promising alternative either. The evidence for the existence of the category of departicipial adjectives is in fact vanishingly small. The often quoted Ved. sáhantya- to *sáh-a-nt-<*seg'h-o-nt- 'überwältigend' is completely isolated and may just as well be analogical as has been suggested already by Hoffmann, see "Ved. santya- und ahd. samfti, ags. sēfte", Münchener Studien zur Sprachwissenschaft 23 (1968), 29ff. Note that the Celtic congener *Segontio- may be due to the popularity of secondary and purely structural *io-derivatives to nouns/adjectives with overtly agentive semantics.

On a side note and just to be exhaustive in the account of all the theoretical possibilities, one might also want to consider a departicipial feminine abstract noun $* H_{l}(e) i s H_{2}-(o) n t-(i) i e H_{2}-(\mathrm{cf}$. the popular Lat. (!) category of abstracts in -ent-ia $<*-n t-)$. The meaning would of course be close to the one proposed for the deverbal abstract * $\mathrm{H}_{1} \mathrm{oisH}_{2} \mathrm{eH}_{2}$, for which see above. 
ESSZI = SNOJ, Marko (2009) Etimološki slovar slovenskih zemljepisnih imen. Ljubljana: Založba Modrijan in Založba ZRC, ZRC SAZU.

EWAia = MAYRHOFER, Manfred (1992-2001) Etymologisches Wörterbuch des Altindoarischen I-III. Heidelberg: Carl Winter Universitätsverlag.

FRAU, Giovanni (1978) Dizionario toponomastico Friuli-Venezia Giulia. Udine: Istituto per l'enciclopedia del Friuli-Venezia Giulia.

FURLAN, Metka (2002) „Predslovanska substratna imena v slovenščini.“ Jezikoslovni zapiski 8/2, 29-35.

GARCÍA RAMÓN, José Luis (1986) „Griego đớouat.“ In: A. Etter (ed.), o-o-pe-rosi. Festschrift für Ernst Risch zum 75. Geburtstag. Berlin/New York: Walter de Gruyter, 497-514.

GOTŌ, Toshifumi (1993) "Materialien zur eine Liste altindischer Verbalformen." Bulletin of the National Museum of Archaeology (Osaka) 18, 191-141.

GREULE, Albrecht (2007) Etymologische Studien zu geographische Namen in Europa. Ausgewählte Beiträge 1998-2006. Ed. by W. Janka/M. Prinz. Regensburg: edition vulpes.

IEW = POKORNY, Julius (1959-1969) Indogermanisches etymologisches Wörterbuch. Bern/München: Francke.

ЯНАКИЕВА, Светлана (2009) Тракийската хидронимия. София: Академично издателство „Проф. Марин Дринове

KELLENS, Jean (1995) Liste du verbe avestiques. Wiesbaden: Dr. Ludwig Reichert Verlag.

KRAHE, Hans (1964) Unsere ältesten Flussnamen. Wiesbaden: Otto Harrassowitz.

KRAHE, Hans (1953) „Alteuropäische Flußnamen.“ Beiträge zur Namenforschung 4, 37-53, 105-122, 234-243.

LEJEUNE, Michel (1974) Manuel de la langue vénète. Heidelberg: Carl Winter Universitätsverlag.

LIV $^{2}=$ RIX, Helmut/Martin KÜMMEL/Thomas ZEHNDER/Reiner LIPP/Brigitte SCHIRMER (2001) Lexikon der indogermanischen Verben. Die Wurzeln und ihre Primärstammbildungen. Zweite, erweiterte und verbesserte Auflage bearbeitet von Martin Kümmel und Helmut Rix. Wiesbaden: Dr. Ludwik Reichert Verlag.

LVen. = PELLEGRINI, Giovan Battista/Aldo Luigi PROSCODIMI (1967) La lingua venetica I-II. Padova/Firenze: Istituto di glottologia dell'Università di Padova/ Circolo linguistico fiorentino.

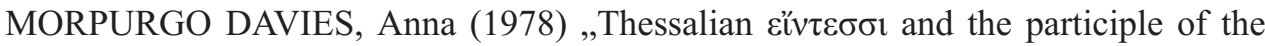
verb 'to be'. "In: Étrennes de septantaine. Travaux de linguistique et de grammaire comparée offerts à Michel Lejeune par un groupe de ses Élèves. Paris: Éditions Klincksieck, 157-166.

NIEDERMANN, Max (1931) „Zur altillyrischen Toponomastik.“ Zeitschrift für Ortsnamenforschung 7, 3-8.

PETERS, Martin (1980) Untersuchungen zur Vertretung der indogermanischen Laryngale im Griechischen. Wien: Verlag der Österreichischer Akademie der Wissenschaften. 
Ramovš, HG II = RAMOVŠ, Fran (1924) Historična gramatika slovenskega jezika II: Konzonantizem. Ljubljana: Učiteljska tiskarna.

RAMOVŠ, Fran (1936) Kratka zgodovina slovenskega jezika. Ljubljana: Akademska založba, 1936.

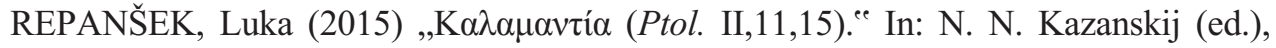
Индоевропейское языкознание и классическая филология/Indo-European Linguistics and Classical Philology - 19. Материалы чтений, посвященных памяти Иосифа Моисеевича Тронского/Proceedings of the 19th Conference in Memory of Professor Joseph M. Tronsky, 22-24 июня 2015 г./June 22-24, 2015, 780-790.

SCHERRER, Peter (2002) „Von Regnum Noricum zur römischen Provinz: Grundlagen und Mechanismen der Urbanisierung. .e In: M. Šašel Kos/P. Scherrer et al. (eds.), The autonomous towns of Noricum and Pannonia - Die autonomen Städte in Noricum und Pannonien. Noricum. Ljubljana: Narodni muzej Slovenije, 11-70.

SCHRAMM, Gottfried (1981) Eroberer und Eingesessene. Geographische Lehnnamen als Zeugen der Geschichte Südosteuropas im ersten Jahrtausend n.Chr. Stuttgart: Anton Hiersmann.

SIMBECK, Katrin/Wolfgang JANKA (eds.) Namen in Altbayern. Gesammelte Beiträge zu Ehren von Josef Egginger und Günter Schneeberger. Regensburg: Edition vulpes.

STEENWIJK, Han (1992) The Slovene dialect of Resia: San Giorgio. Amsterdam: Rodopi.

STIFTER, David (2010) „On the linguistic situation of Roman-period Ig." In: T. Meißner (ed.), Personal names in the Western Roman world. Proceedings of a workshop convened by Torsten Meißner, José Luis García Ramón and Paolo Poccetti, held at Pembroke College, Cambridge, 16-18 September 2011. Berlin: Curach bhán, 247-265.

SVI = BEZLAJ France (1956-1961) Slovenska vodna imena I-II. Ljubljana: SAZU.

ŠAŠEL, Jaroslav (1972) ,Zur Erklärung der Inschrift am Tropaeum Alpium (Plin. $n . h$. 3, 136-137. CIL V 7817). “ Živa antika 22, 135-144.

ŠAŠEL KOS, Marjeta (1997) „The end of the Norican kingdom and the formation of the provinces of Noricum and Pannonia." In: B. Djurić/I. Lazar (eds.), Akten des IV. Internationalen Kolloquiums über Probleme des provinzialrömischen Kunstschaffens, Celje, 8.-12. Mai 1995 - Akti IV. mednarodnega kolokvija o problemih rimske provincialne umetnosti, Celje, maj 1995. Ljubljana: Narodni muzej Slovenije, 21-42.

ŠEKLI, Matej (2008) Zemljepisna in osebna lastna imena $v$ kraju Livek in njegovi okolici. Ljubljana: Založba ZRC, ZRC SAZU.

ŠEKLI, Matej (2009) „On Romance-Alpo-Slavic substitutional accentology: the case of pre-Slavic masculine substrate place names in Slovene. "e In: Th. Olander/J. H. Larsson, Stressing the past, Papers on Baltic and Slavic Accentology. Amsterdam/ New York: Rodopi, 145-160.

ŠIVIC-DULAR, Alenka (1998) „Lingvistička definicija vlastite imenice. “ Folia onomastica Croatica 7, 281-293. 
ŠTURM, Fran (1927) „Refleksi romanskih palataliziranih konzonantov v slovenskih izposojenkah. "Časopis za slovenski jezik, književnost in zgodovino 6, 45-85.

TAVANO, Sergio (ed.) (1972) Aquileia e l'Alto Adriatico 2: Aquileia e l'Istria. Udine: Arti grafiche Friulane.

VEDALDI IASBEZ, Vanna (1994) Venetia orientale e l'Histria. Le fonti letterarie greche e latine fino alla caduta dell'Impero Romano d'Occidente. Roma: Edizioni Quasar.

WERBA, Chlodwig H. (1997) Verba Indoarica. Die primären und sekundären Wurzeln der Sanskrit Sprache. Pars I: Radices primariae. Wien: Verlag der Österreichischer Akademie der Wissenschaften.

\section{Abstract \\ TOWARDS A CLARIFICATION OF THE HISTORY OF THE SLOVENE RIVER NAME SOČA}

The etymology of the Slovene hydronym Soča (Standard Friulan Lusìnç, Italian Isonzo) was satisfactorily elucidated more than half a century ago. The overall idea that the river name goes back to a derivative of a Proto-Indo-European verbal root ${ }^{*} \mathrm{H}_{1}$ eis $\mathrm{H}_{2}$ - is undoubtedly correct (the exact meaning of the root in question has, however, not been sufficiently corroborated) but the details remain hopelessly obscure. Given the contemporary reflexes of the underlying name (viz. Friulan Lusinç $\sim$ dial. Lisùns etc.) and the sometimes conflicting or not at all easily reconcilable historical attestations (spanning nearly a millenium), no consensus can in fact be reached about the exact formal means involved in the derivation of the original deverbative formation - a fact which results from the overall inconvenience of sheer wealth of combinatorial possibilities that go hand in hand with the general ambiguity of the phonology more or less directly reflected by the later reflexes of the name. The present contribution is an attempt at unifying all the reliable data at our disposal into a coherent picture that would bring a satisfactory answer as to the exact phonological and morphological make-up of the prehistoric source (alongside with the reconstructed meaning) and its subsequent history as it passed through the various linguistic strata.

Keywords: Soča, Indo-European hydronymy, Slavic, Romance, pre-Slavic substratum

\section{Povzetek PRISPEVEK K ZGODOVINI SLOVENSKEGA REČNEGA IMENA SOČA}

Etimologija imena Soča (standardno furlansko Lusìnç, italijansko Isonzo) je bila sicer zadovoljivo razjasnjena že pred več kot pol stoletja. Ime je brez dvoma treba izpeljevati iz praindoevropskega korena ${ }^{*} H_{1} e i s H_{2}-\mathrm{s}$ sicer težje ugotovljivo prvotno semantiko, vendar se v poizkusu natančnega spremljanja zgodovinskega razvoja imena od njegove prvotne podobe do sodobnih kontinuantov (predvsem furl. Lusinç narečno Lisùns 
itd.) izkaže, da kopica bistvenih dejstev ostaja nerazjasnjenih. Splošna večznačnost fonetične podobe organskih kontinuantov, vključno s skopimi in težje pojasnljivimi podatki, ki jih ponuja skoraj tisočletje zelo sporadičnih historičnih zabeležb imena, je v neposredni vzročni povezanosti z množico verjetnih (in mnogokrat povsem teoretičnih) kombinatoričnih možnosti rekonstrukcije formalnih sredstev, vpletenih pri tvorbi izhodnega deverbativa. V prispevku se pod vprašaj ponovno postavlja vse relevantno in zanesljivo gradivo, ki bi, povezano $\mathrm{v}$ smiselno in kronološko prepričljivo izgrajeno celoto, utegnilo odgovoriti na vprašanje o natančni fonetični in morfološki podobi izhodne oblike (in posledično njenem prvotnem pomenu) ter pojasniti vse razvidne spremembe substitucijske narave, do katerih je zanesljivo prihajalo pri prehajanju hidronima skozi različne jezikovne sisteme.

Ključne besede: Soča, indoevropska hidronimija, slovanščina, romanščina, predslovanski substrat 